\title{
Spatial and Temporal Variation of Rainfall in Ninava Governorate
}

\author{
Lamia M. F. Mustafa \\ Department of Physics / College of Education \\ University of Mosul
}

Received

05 / 01 / 2011
Accepted

29 / 06 / 2011

\section{الملغص}

قم درلسة تساقط الأطار في أربعة مواقع في محاظظة نينوى، وهي الموصل وسنجار

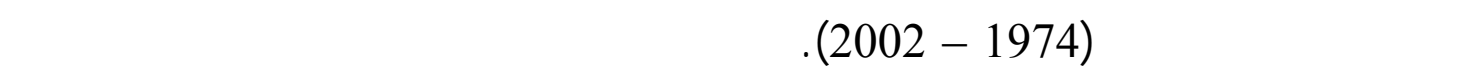

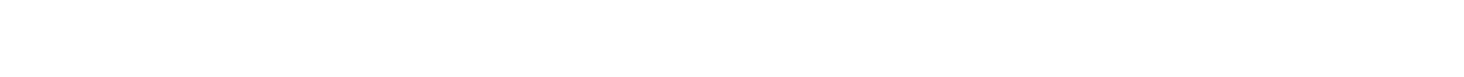

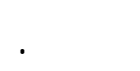

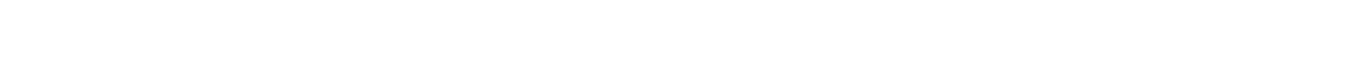

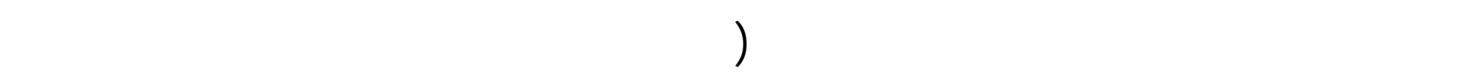

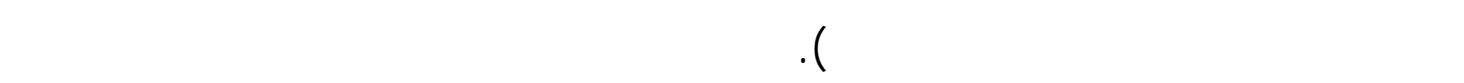
اللشهرية اللساظة ضمن مديك محدة في لكل المواقع.

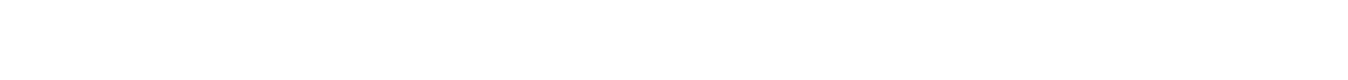

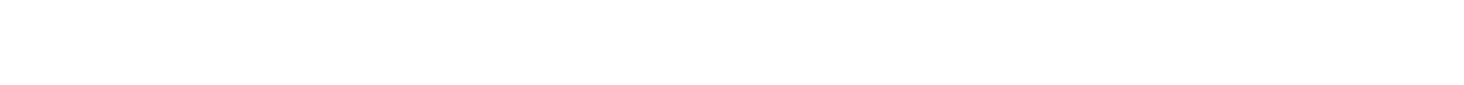

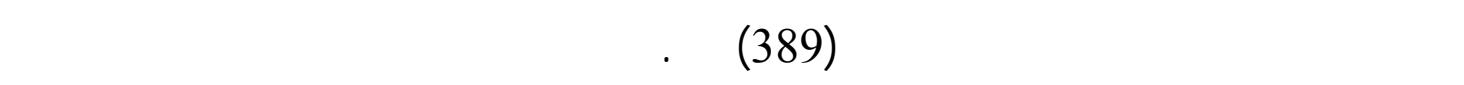

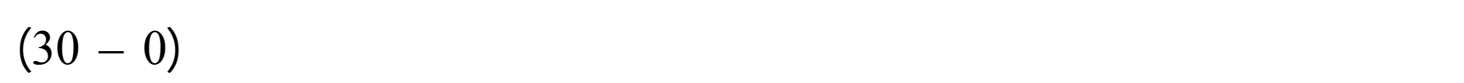

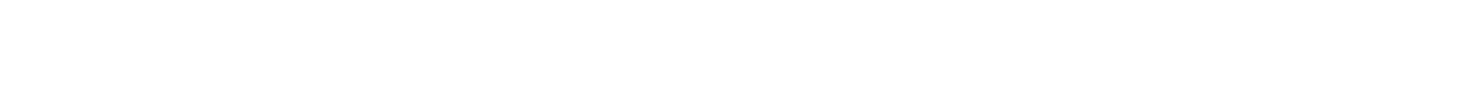
نسبة تكرار صمن المدى (30 - 60) ملم.

\section{Abstract}

Rainfall was studied in four locations in Ninava Governorate which are Mosul, Sinjar and Talafar and Rabea for the period (1974-2002).

The Mean Monthly, Seasonally and Annual values of Rainfall, Standard Deviation, Coefficient of Variation and Time Series for rainfall was studied during there periods in all locations.

Simple and Multiple correlations were found between mean monthly values of rainfall and other Metrological elements (Temperature, 
Relative humidity, Atmospheric pressure, Sunshine, Evaporation, Gloudness). Frequency distribution of rainfall data were also calculated.

The results indicate a simple negative trends in the Time Series of the mean monthly values of rainfall in all locations, The maximum mean annual value of rainfall were found in sinjar location which reach (389) $\mathrm{mm}$. The maximum frequency of rainfall in Oct., Nov., Apr., May were in the range of (0-30) $\mathrm{mm}$ in all stations while Dec., Jan., Feb., March show the maximum frequency in the range of (30-60) $\mathrm{mm}$.

\section{Introduction}

Rainfall analysis is very important in different domains such as: Agricultural planning, Water resources planning, Runoff and Stream Flow Predictions soil Conservation studies, environmental studies, and human life activities[1].

The amount, intensity and areal distribution of rainfall are essential factors in many hydrologic studies[2]. Rainfall varies geographically, temporally and seasonally[3,4].

Bonifacis (2000)[5], He Study the variation of rainfall in philippines during the period (1930 - 1996), He found the 5-year and 10-year moving average and they use same statistical models to evaluate rainfall variability.

Bleeg (2003)[6] study the variation of precipitation with time and space in Dohuk governorate and made a correlations between Rainfall and other meteorological elements.

Dawood (2004)[7] study the time series of the monthly values of rainfall in different Meteorological stations presents in the north part of Iraq

Grimald.(2005)[8] test the multivariate linear Parametric models applied to daily rainfall series, these simple models allow to generate synthetic series preserving both the time correlation (autocorrelation) and the space correlation (cross correlation).

In Andes Wouter, (2006) [9] Study the spatial and temporal rainfall variability in mountainous areas using 14 rain gauges located in western mountain range of the Ecuadorian Andes.

Odure (2006)[10] Take the data of the mean annual rainfall for the period (1961-1998) using data from 30 stations and he subjected the time series to a power spectrum using the max Entropy spectral Analysis technique in Ghana.

Momani (2009)[11] use (Box -Jenkins) model to forecasting the monthly rainfall for the upcoming 10 years in Amman to help decision makers establish priorities in term of water demand management.

Abaje.(2010) [12] Analyze the Rainfall trends in Nigeria using the rainfall data during the period (1974-2008). They found that the trend in the rainfall series is decreasing on the annual basis. 
The objective of this research is to study the variation of Rainfall with space and time in Ninava Governorate using four Meteorological stations (Mosul, Sinjar, Talafar and Rabea). Simple and Multiple correlations were found between mean monthly values of rainfall and other Metrological elements.

\section{Methodology}

Ninava Governorate which is located in the northern part of Iraq contain four main meteorological stations (Mosul, Sinjar, Talafar, Rabea). fig(1) show the locations of these stations.

The latitude, longitude, Altitude and years of observations for these meteorological stations were presented in table (1).

In our research we study

1) Standard deviation and coefficient variation of the monthly values of rainfall were found.

2) Mean monthly rainfall, mean seasonal rainfall and mean annual rainfall. in these four stations

3) Time series of the monthly rainfall values were found in all stations..

4) Simple and multiple regressions equations were found between mean monthly values of rainfall and other Meteorological elements.

5) Frequency distribution of rainfall data were also found in all stations.

\section{Results and Discussion}

1- Study of standard deviations, coefficient of variation and time series of monthly values of rainfall in all stations.

Standard deviation means a measure of the dispersion of a set of data from the mean. A low standard deviation indicates that the points tend to be very close to the means. Standard deviation can be calculated by the following equation:

$$
\mathrm{SD}=\left[\sum(\mathrm{x}-\overline{\mathrm{x}})^{2} / \mathrm{n}-1\right]^{-1 / 2}
$$

The coefficient of variation represents the percentage ratio of standard deviation to the mean, and it's a useful to show the variability of rainfall data. $\mathrm{CV}$ can be calculated by the following equation:

$\mathrm{CV}=(\mathrm{SD} / \overline{\mathrm{x}}) * 100$

In this research we obtain the values of SD and CV by Excel program.

Fig (2) Show the standard deviation (SD)of the monthly values of rainfall in all stations.

The minimum values of SD in the stations (Mosul, Singar, Talafar) are in October where its values are $(17.1,17.4,18.7) \mathrm{mm}$ respectively, While the minimum value of SD in Rabea station is in May (21.1) $\mathrm{mm}$. where its maximum values are $(58.8,54.8,56.8,45.5) \mathrm{mm}$ in (Sinjar, Talafar and Rabea) stations respectively in January, while in Mosul the maximum value was in March (47.6)mm.

Fig (3) Show the coefficients of variation of the monthly values of Rainfall in all stations. The maximum values of CV was obtained in May for Mosul and Sinjar stations with values $(182,156.6) \%$ respectively while Talafar and Rabea stations where its values are $(154.5,124) \%$ in 
October. In Sinjar station the minimum value was in March (63.4), in February for Talafar and Rabea stations $(53,51.4) \%$, While in Mosul the minimum values of CV was obtained in December (55.6)\%.

The Time Series of the monthly values of rainfall in all stations were shown in Fig.(4, 5, 6,7).

From the Figures its clear that all the stations have unsteady series. The trends of the series shows a small decrease with time in years in the four stations.

The mean monthly values of rainfall, Standard Deviation, Coefficient of Variations were shown in appendix (1).

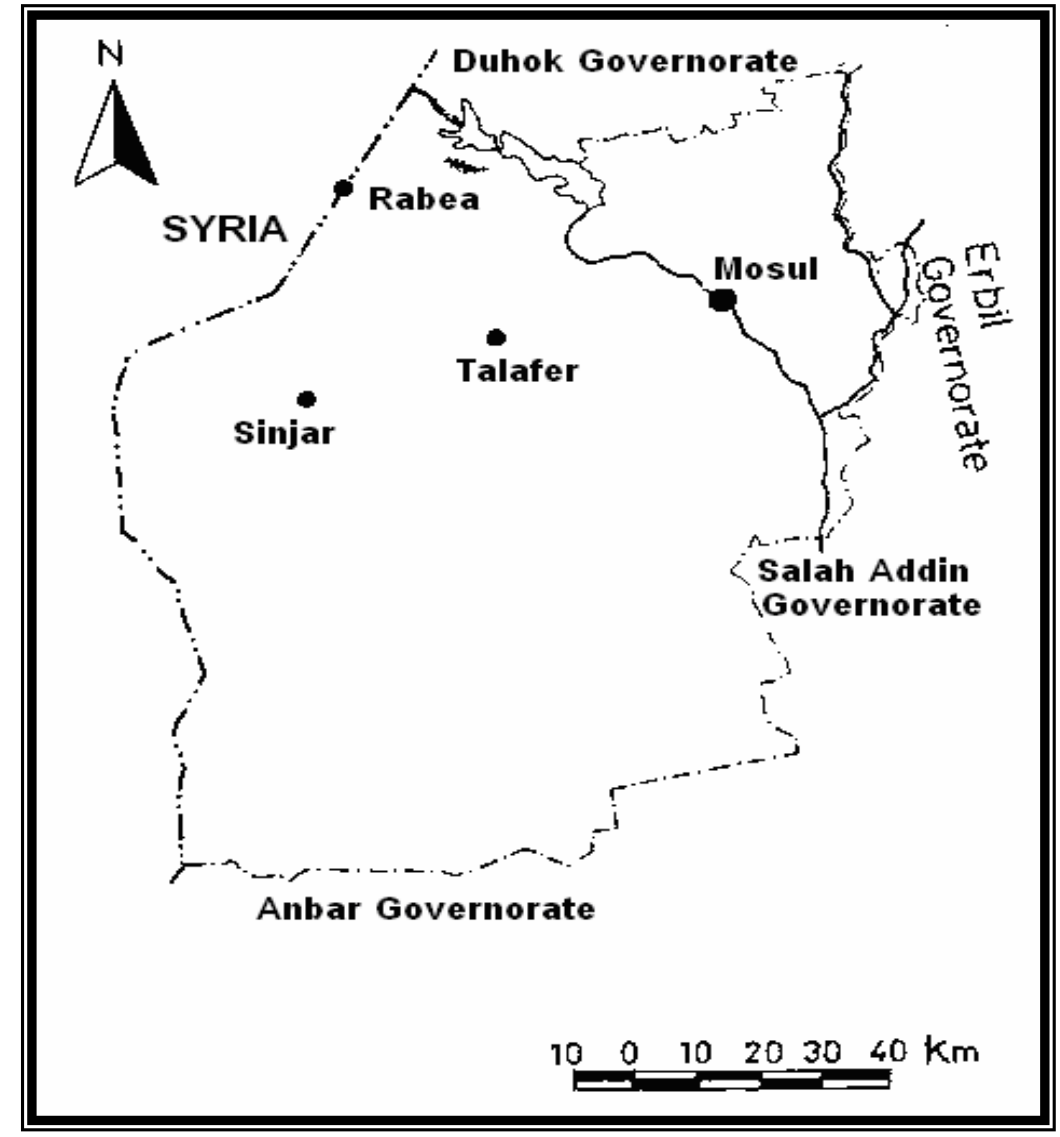

Fig. (1): Ninava Governorate Map

Table (1): The selected stations in Ninava Governorate and their geographic information.

\begin{tabular}{|c|c|c|c|c|}
\hline Stations & latitude & Longitude & Altitude (m) & $\begin{array}{c}\text { Years of } \\
\text { observations }\end{array}$ \\
\hline Mosul & $36^{\circ} 19^{-}$ & $43^{\circ} 09^{-}$ & 223 & (1974-2002) \\
\hline Sinjar & $36^{\circ} 19^{-}$ & $41^{\circ} 50^{-}$ & 538 & (1974-2002) \\
\hline Talafer & $36^{\circ} 22^{-}$ & $42^{\circ} 28^{-}$ & 273 & (1974-2002) \\
\hline Rabea & $36^{\circ} 48^{-}$ & $42^{\circ} 06^{-}$ & 382 & (1974-2002) \\
\hline
\end{tabular}



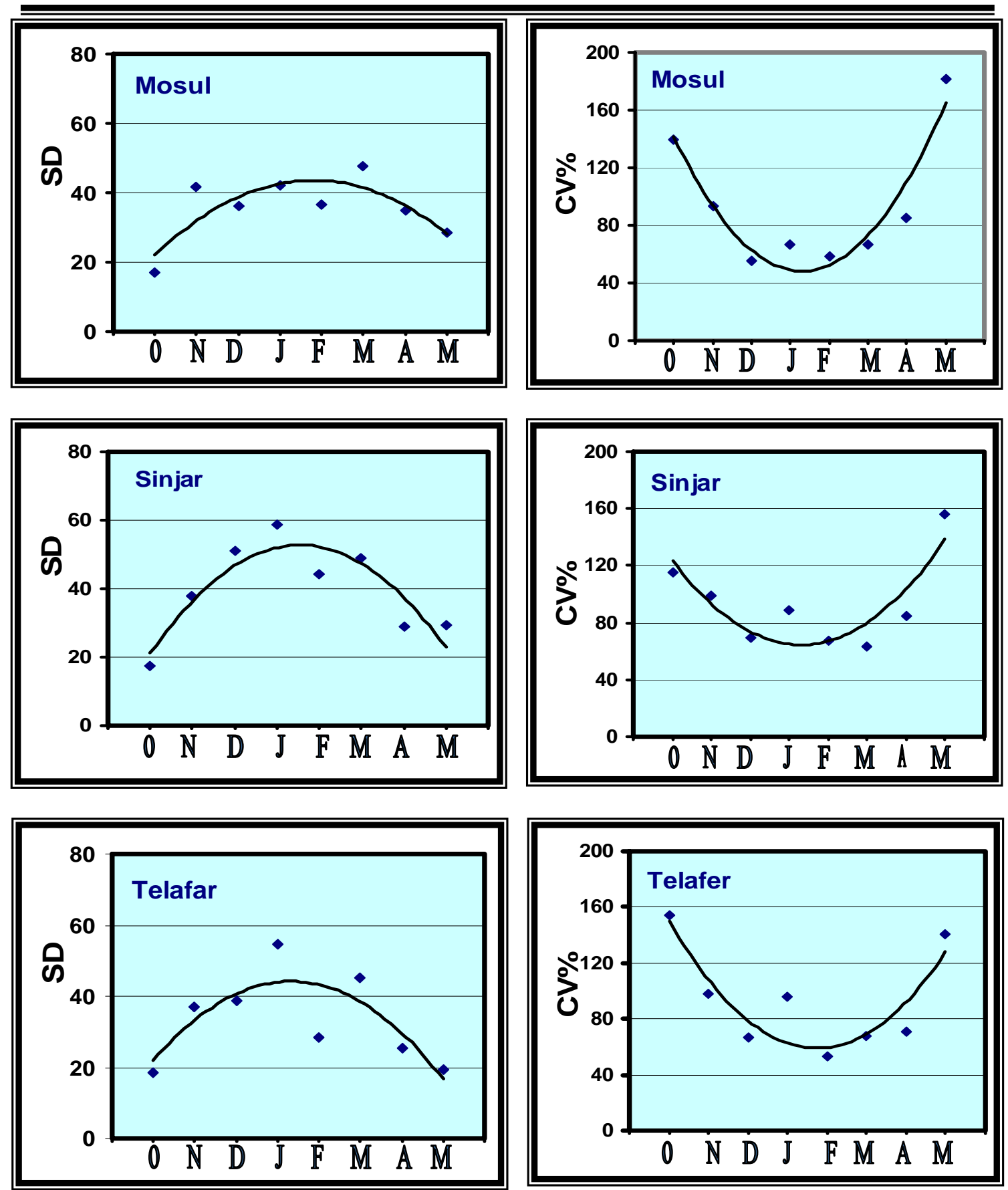

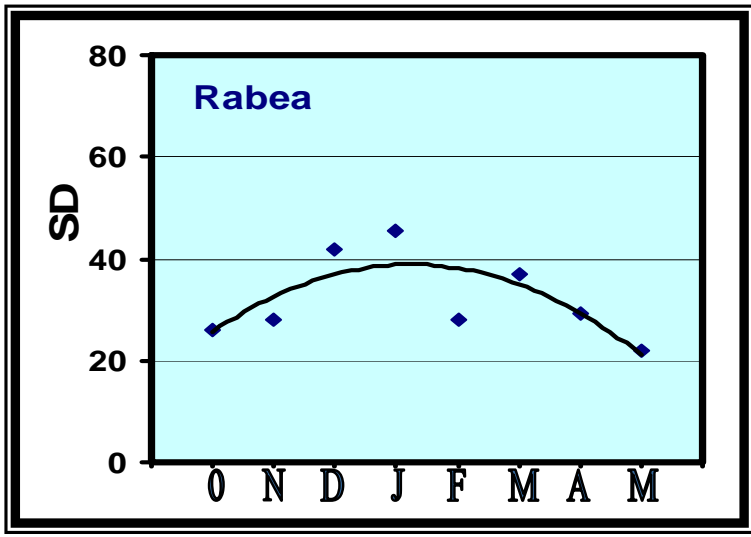

Fig (2): Standard Deviations of the monthly values of rainfall in the four stations

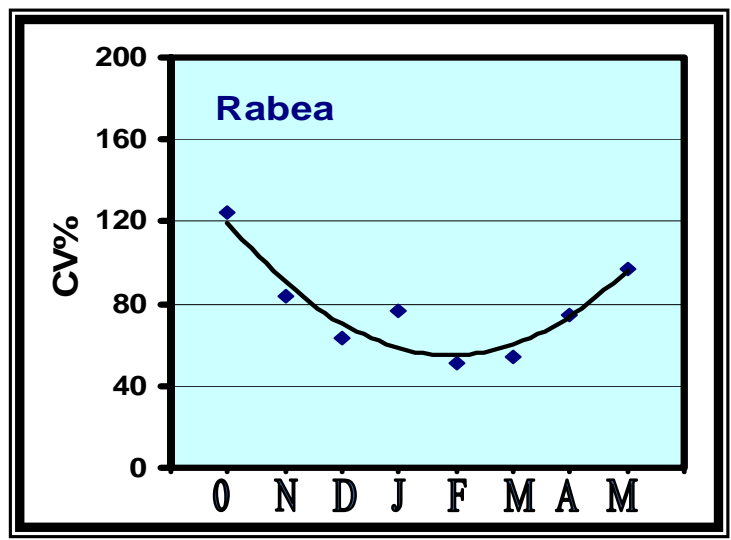

Fig (3): Coefficients of Variation of monthly values of rainfall in the four stations 
Spatial and Temporal Variation of Rainfall in Ninava Governorate.

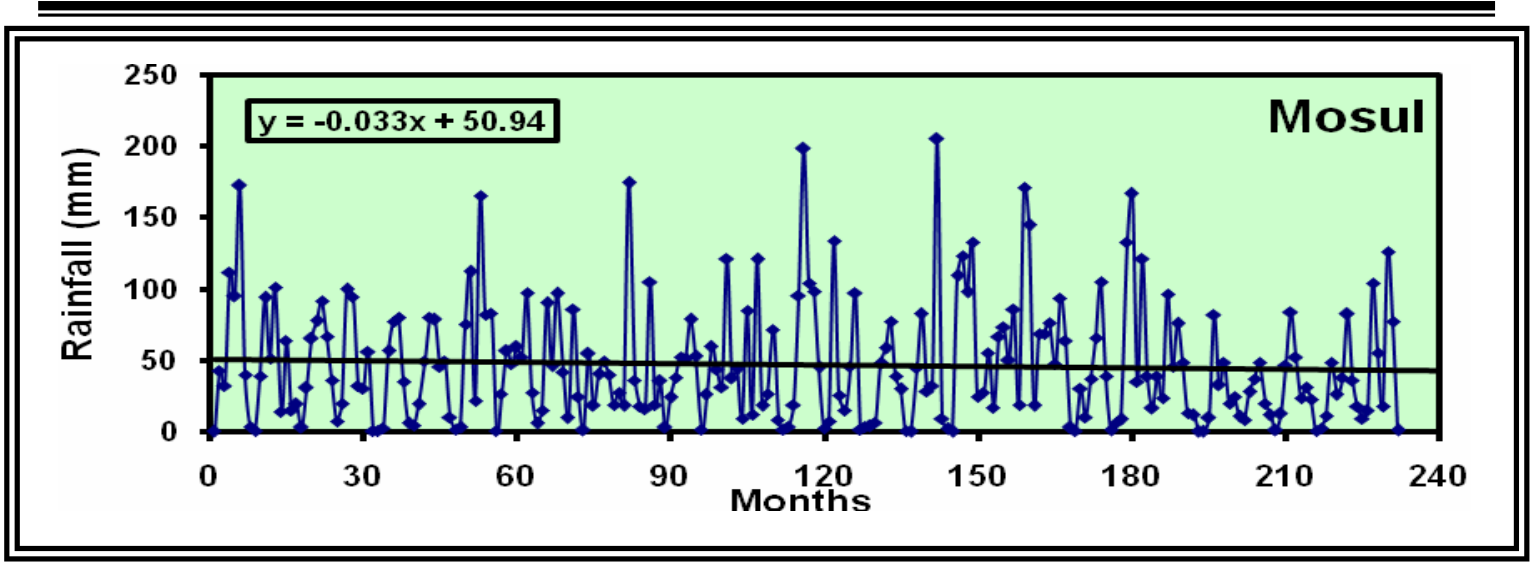

Fig(4):Time Series for Monthly Values of Rainfall in Mosul Station for the period (1974-2002)

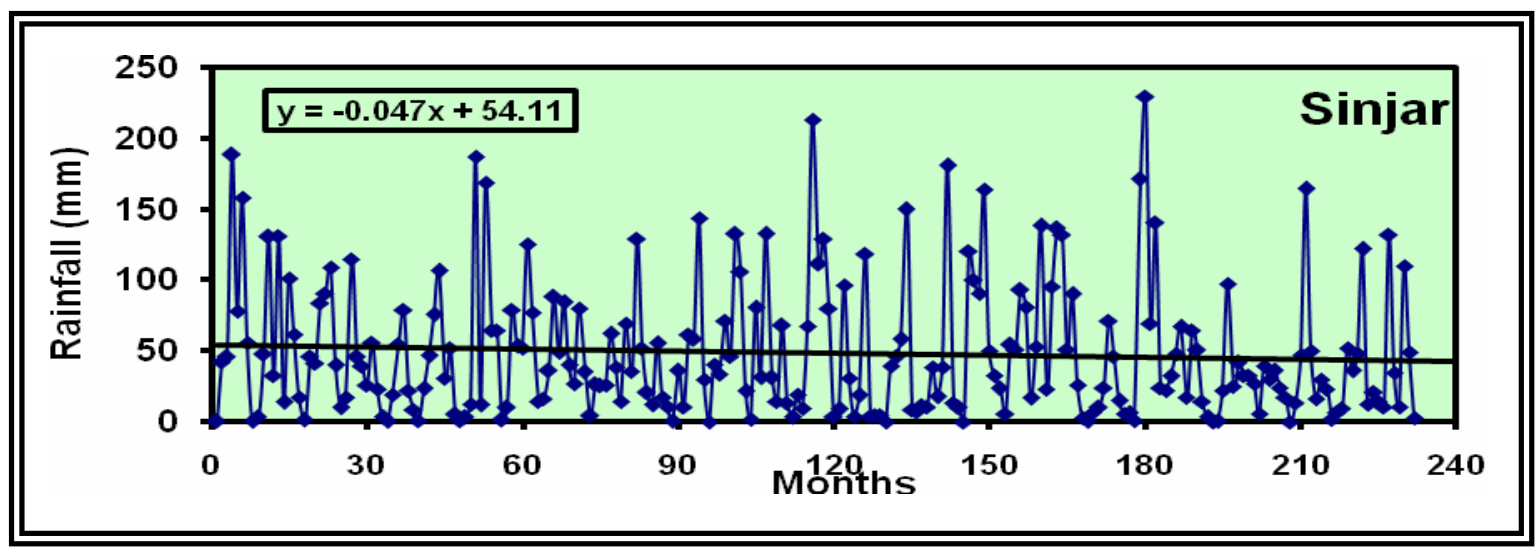

Fig(5): Time Series for Monthly Values of Rainfall in Sinjar Station for the period (1974-2002)

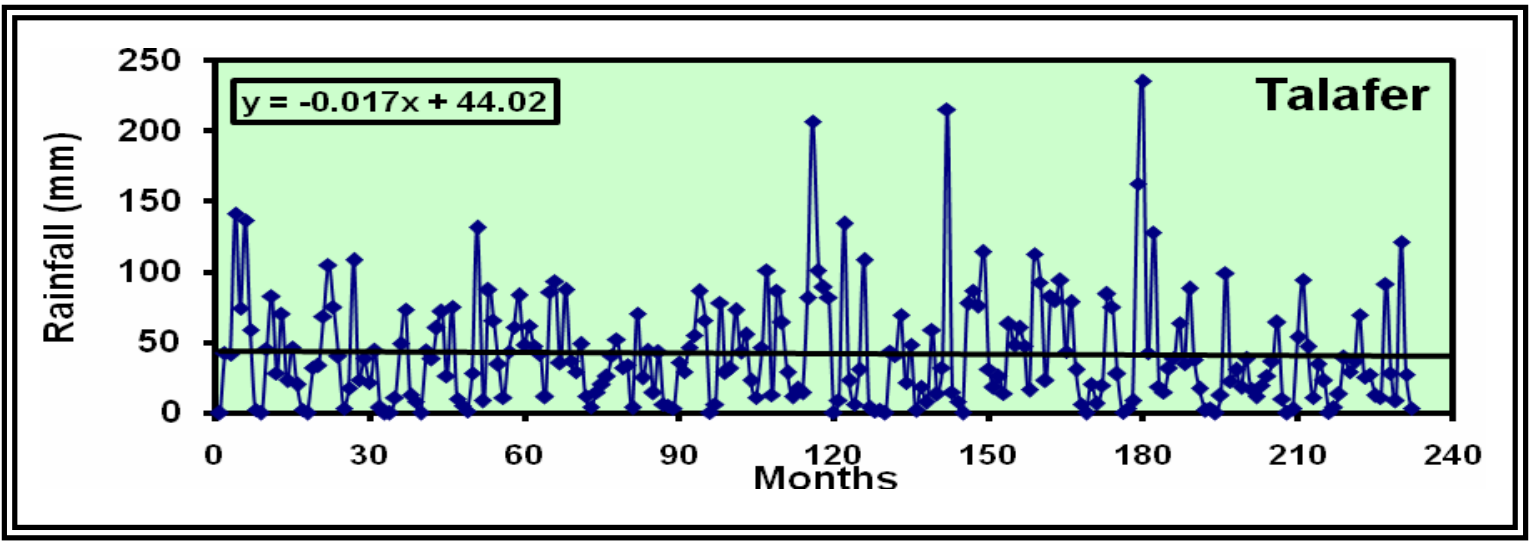

Fig(6):Time Series for Monthly Values of Rainfall in Talafar Station for the period (1974-2002)

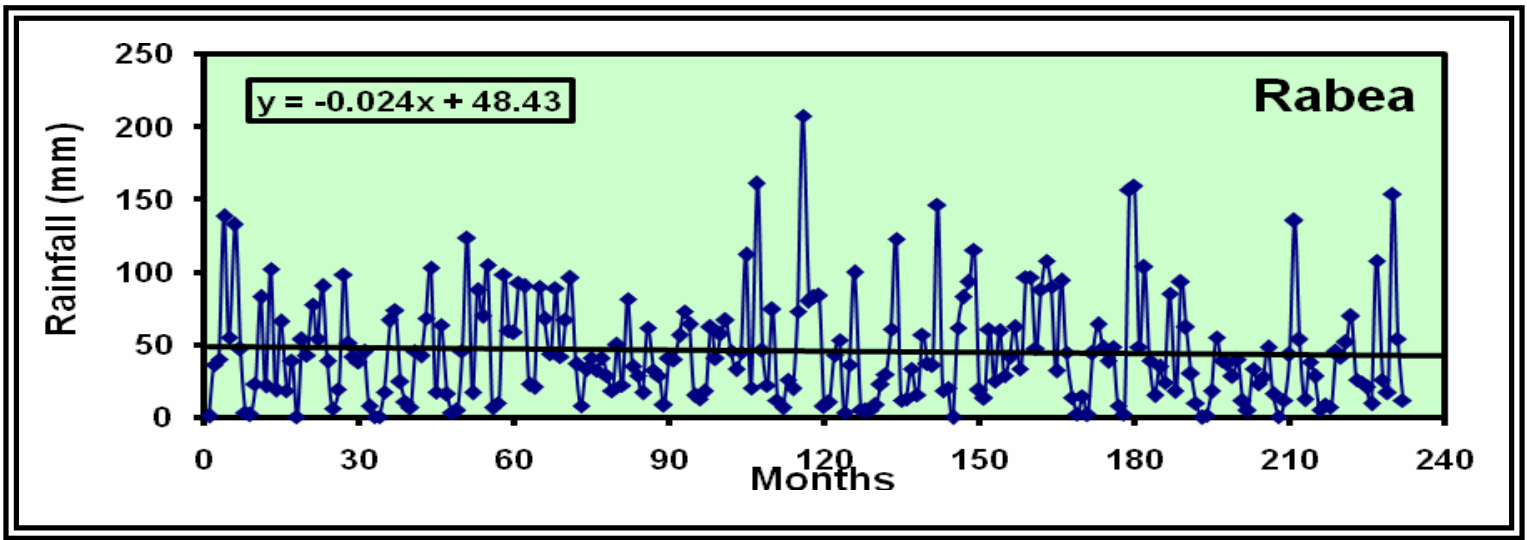

Fig(7) :Time Series for Monthly Values of Rainfall in Rabea Station for the period (1974-2002) 
2- Study of mean monthly, Seasonally and Annually rainfall in all stations.

Fig (8) Shows the mean monthly values of rainfall $(\mathrm{mm})$ for the different stations in Ninava Governorate. We can see that:

A- May and October gives the lowest values of rainfall in all stations in comparing with the other rainy months.

B- November and April gave a value of rainfall ranged between (33.6 44.6) $\mathrm{mm}$ in all stations.

C- December, January, February, March gave the highest values of rainfall in comparing with the other rainy months in all stations, where the value of rainfall ranged between $(53.8-77.2) \mathrm{mm}$.

D- The minimum values of rainfall in all stations were obtained in October where it is value ranged between $(12.3-21) \mathrm{mm}$.

E- The maximum value of rainfall in all stations were obtained in March where it is ranged between $(66.3-77.2) \mathrm{mm}$.

From this fig. we see that Sinjar and Rabea have a good amount of rainfall in all months and this help the agriculture in this places.

Fig. (9) Shows the mean seasonal values of rainfall in all stations presents in Ninava Governorate.

Winter season receives about (156.4-203.4)mm of rainfall, Spring season receive available amount of rainfall and contributes between (110-133) $\mathrm{mm}$. The autumn season contribute between $(51-57) \mathrm{mm}$.

Fig. (10) Shows the mean annual values of rainfall for all stations which can be arranged from the highest value to the lowest values as: $389.1 \mathrm{~mm}$ in Sinjar, $355.1 \mathrm{~mm}$ in Rabea, $378.8 \mathrm{~mm}$ in Mosul and 317.7 $\mathrm{mm}$ in Talafar.

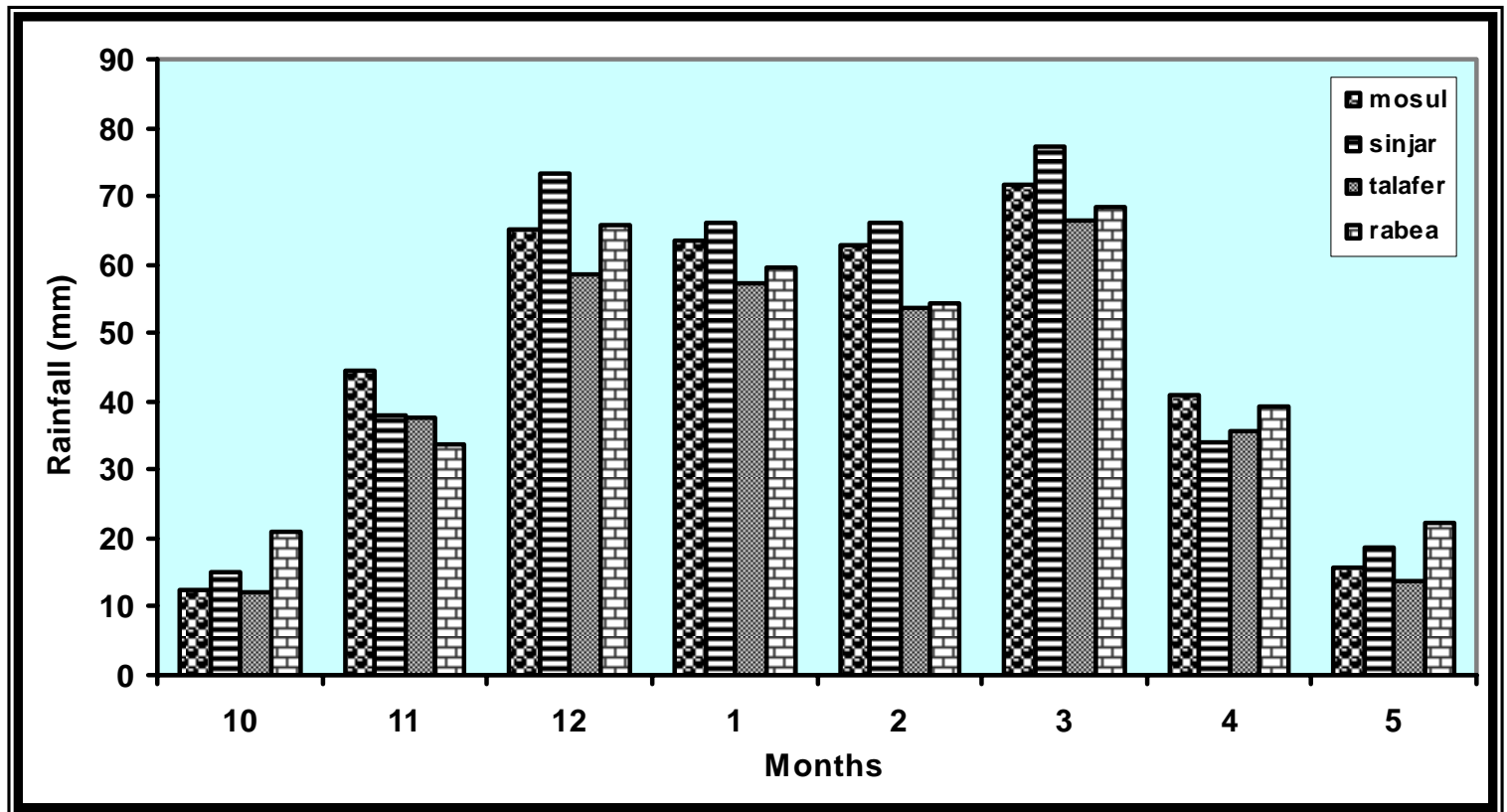

Fig.(8): Mean Monthly values of rainfall(mm) For all stations. 
Spatial and Temporal Variation of Rainfall in Ninava Governorate.

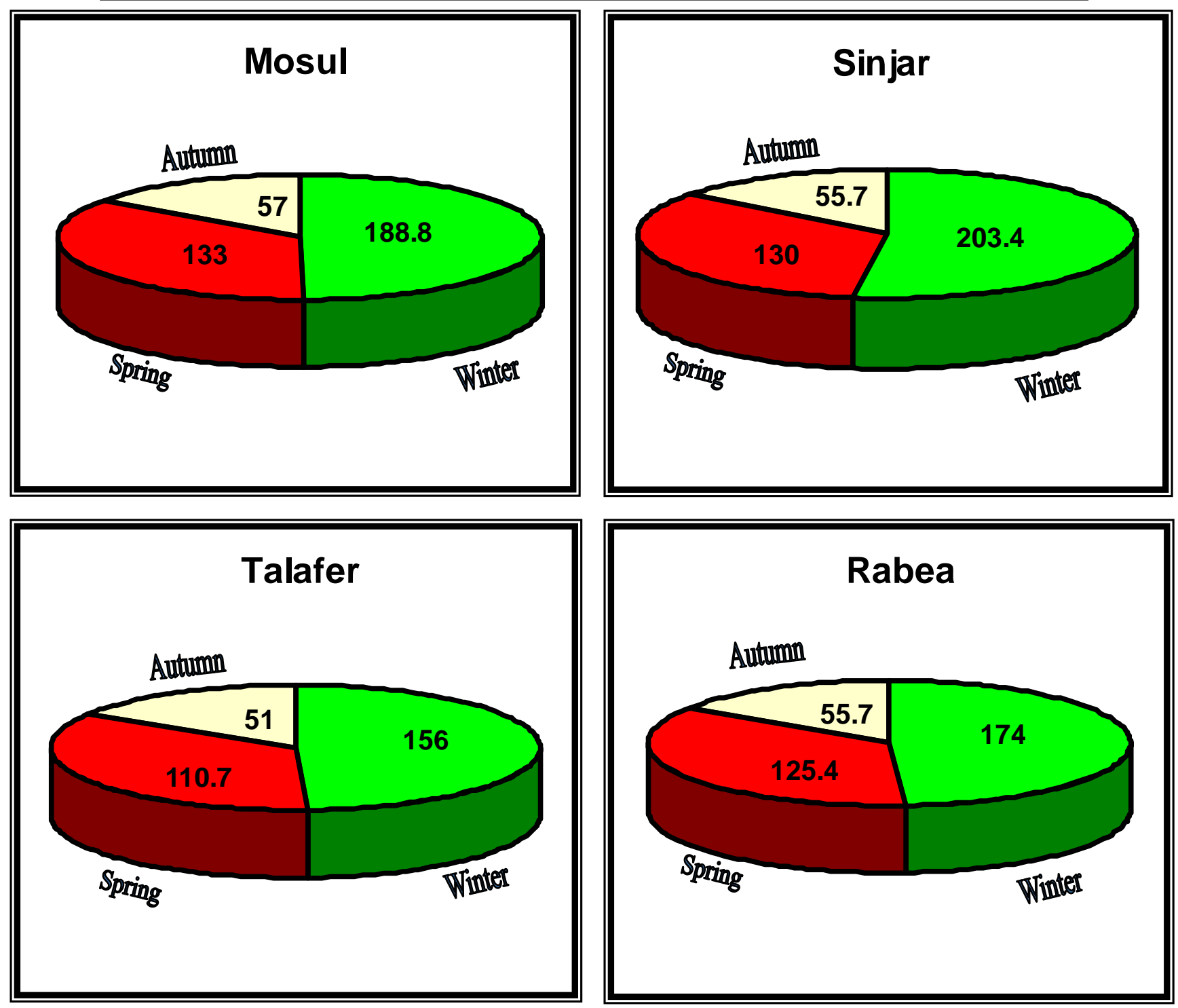

Fig. (9): Mean Seasonal Values of rainfall in $(\mathrm{mm})$ for all stations

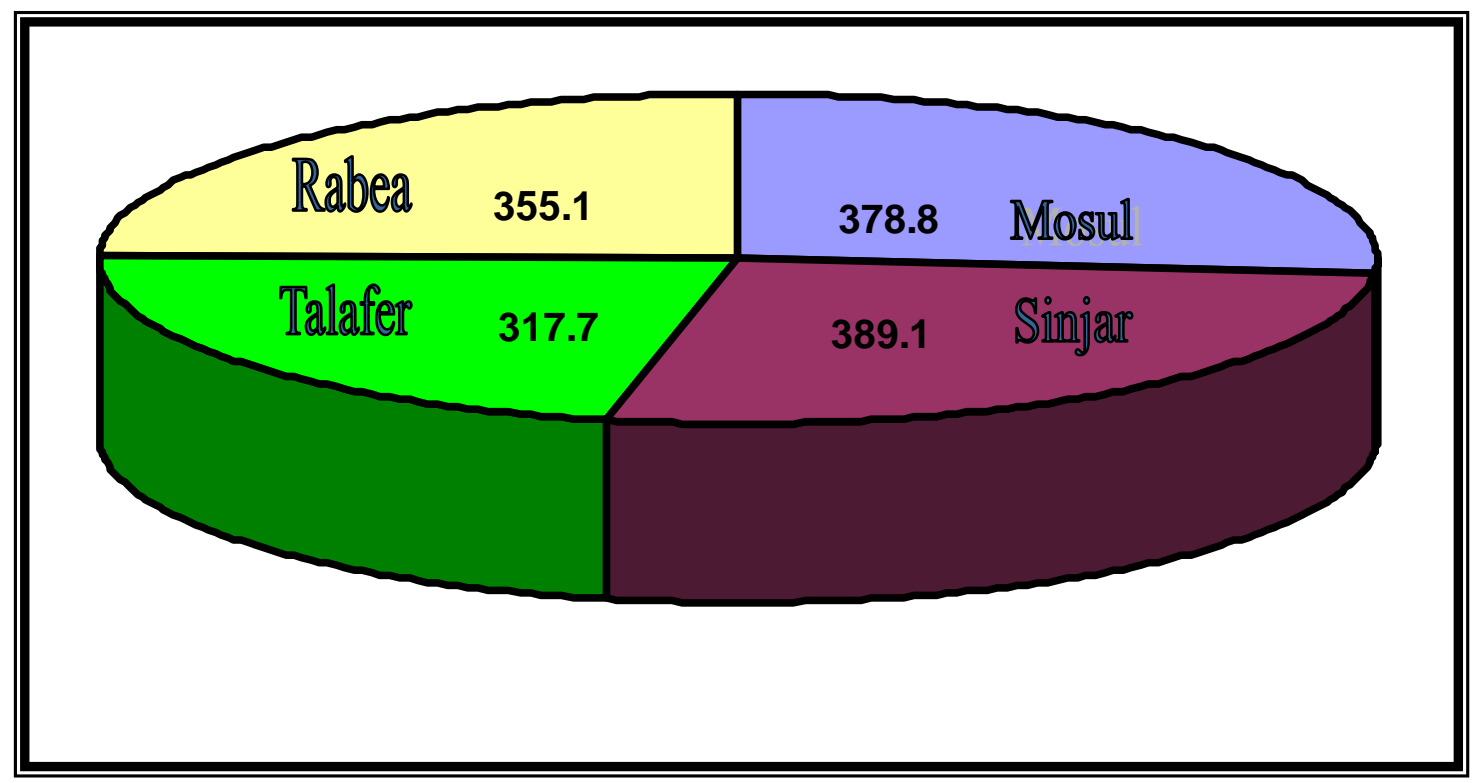

Fig. (10): Mean Annual values of rainfall in ( $\mathrm{mm})$ for all stations 
3- Correlations between the mean monthly values of rainfall and the mean monthly values of the different meteorological elements in all stations.

Fig (11) Shows the correlations between the mean monthly values of rainfall and mean air temperature in all stations.

A highly negative correlation were obtained in all stations and the values of the correlation coefficient $(\mathrm{R})$ for all stations are $(-0.91,-0.92$, - 0.89, - 0.90) in Mosul, Sinjar Talafar, and Rabea stations respectively.

Fig (12) Shows a highly positive correlation between mean monthly values of rainfall and relative humidity, where the values of $(R)$ are $(0.93$, $0.91,0.88,0.86)$ in Mosul, Sinjar, Talafar and Rabea stations respectively.

Fig (13) Shows a highly negative correlation between mean monthly values of rainfall and evaporation in $(\mathrm{mm})$ in all stations. Where the values of $(\mathrm{R})$ are $(-0.85,-0.81,-0.86,-0.75)$ in Mosul, Sinjar, Talafer, and Rabea stations respectively.

Fig (14) Shows a highly negative correlation between mean monthly values of rainfall $(\mathrm{mm})$ and a sunshine hours for all stations. Where the values of $(\mathrm{R})$ are $(-0.82,-0.81,-0.80,-0.78)$ on Mosul, Sinjar, Talafar, and Rabea stations respectively.

Fig (15) Show a positive correlation between mean monthly values of rainfall $(\mathrm{mm})$ and atmospheric pressure $(\mathrm{mb})$ for all stations. Where the values of $(\mathrm{R})$ are $(0.70,0.68,0.70,0.63)$ on Mosul, Sinjar, Talafar and Rabea stations respectively.

Fig (16) Shows appositive correlation between mean monthly values of rainfall $(\mathrm{mm})$ and cloudiness (octa) for all stations. Where the values of (R) are $(0.85,0.60,0.89,0.70)$ on Mosul, Sinjar, Talafar and Rabea stations respectively.

A multiple correlation were obtained between the mean monthly values of rainfall and mean monthly values of the meteorological elements (Temperature, Relative Humidity, Atmospheric pressure, Evaporation, Sunshine hours, Cloudiness).

Table (2) Show these multiple correlations and their correlation coefficients These correlations are very important for hydrological and Climatologically studies.

Table (2): Multiple correlations equations and correlation coefficients for all stations.

\begin{tabular}{|c|c|c|}
\hline stations & Equations & $\mathbf{R}$ \\
\hline Mosul & $\begin{array}{c}\mathrm{R}=44932.828-5.897 \mathrm{~T}-44.223 \mathrm{P}+12.254 \mathrm{RH}+7.975 \mathrm{n}- \\
\text { 1.005EVAP }-150.907 \mathrm{C} \\
\end{array}$ & 1 \\
\hline Sinjar & $\begin{array}{c}\mathrm{R}=-24465.2-5.775 \mathrm{~T}+23.792 \mathrm{P}-0.987 \mathrm{RH}+6.548 \mathrm{n}+1.448 \\
\text { EVAP + 66.015C }\end{array}$ & 0.956 \\
\hline Talafer & $\begin{array}{c}\mathrm{R}=2933.872-4.391 \mathrm{~T}-2.66 \mathrm{P}-2.485 \mathrm{RH}+7.369 \mathrm{n}-0.38 \mathrm{EVAP}+ \\
10.525 \mathrm{C}\end{array}$ & 0.955 \\
\hline Rabea & $\begin{array}{c}\mathrm{R}=3192.522-7.167 \mathrm{~T}-3.226 \mathrm{P}+2.166 \mathrm{RH}+35.015 \mathrm{n}- \\
\text { 0.618EVAP }-27.688 \mathrm{C}\end{array}$ & 0.998 \\
\hline
\end{tabular}


Spatial and Temporal Variation of Rainfall in Ninava Governorate.
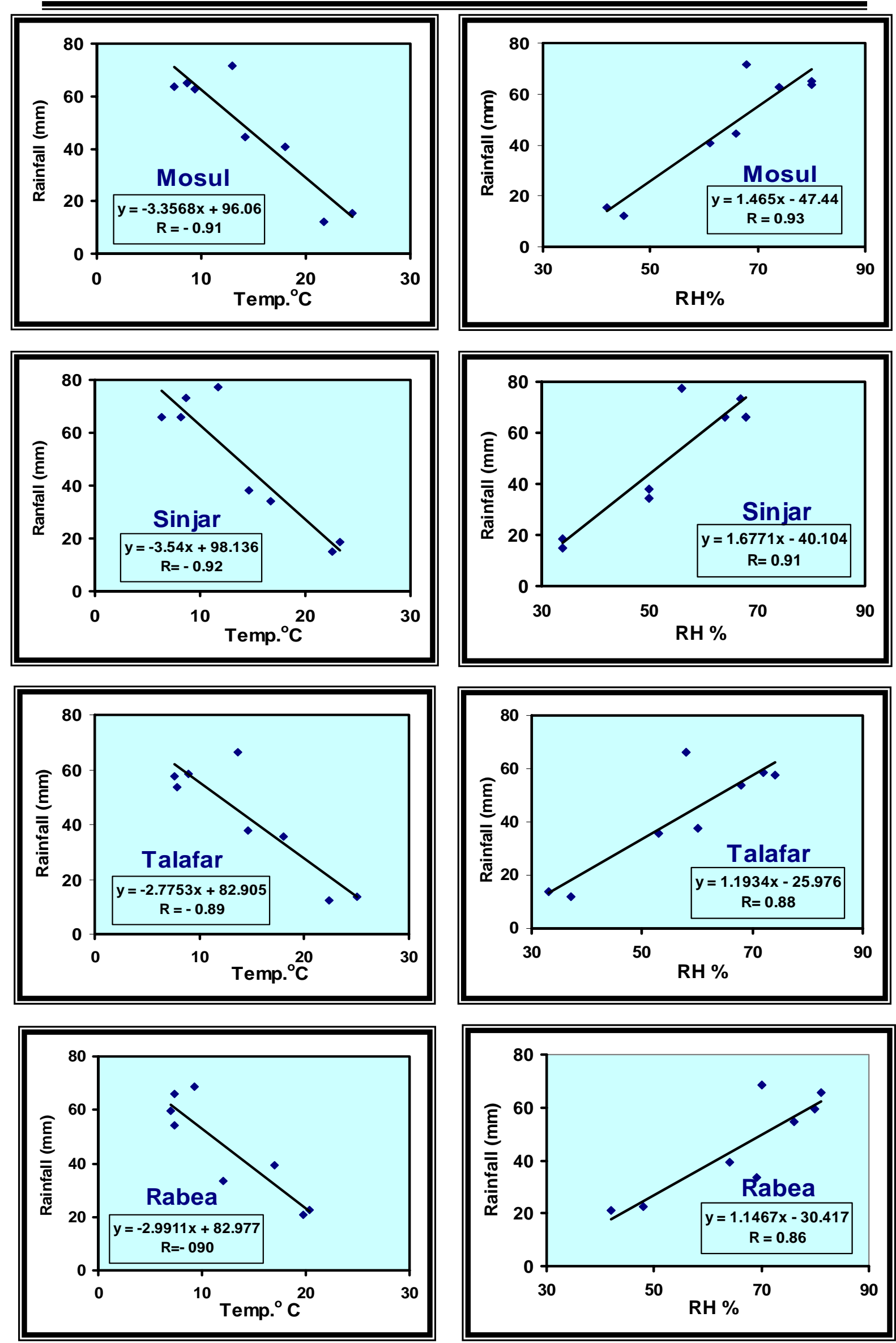

Fig. (11) : Correlations between the mean Monthly Values of Rainfall (mm) and mean air Temp. for all Stations

Fig. (12) : Correlations between the mean Monthly Values of Rainfall and Relative Humidity for all Stations 

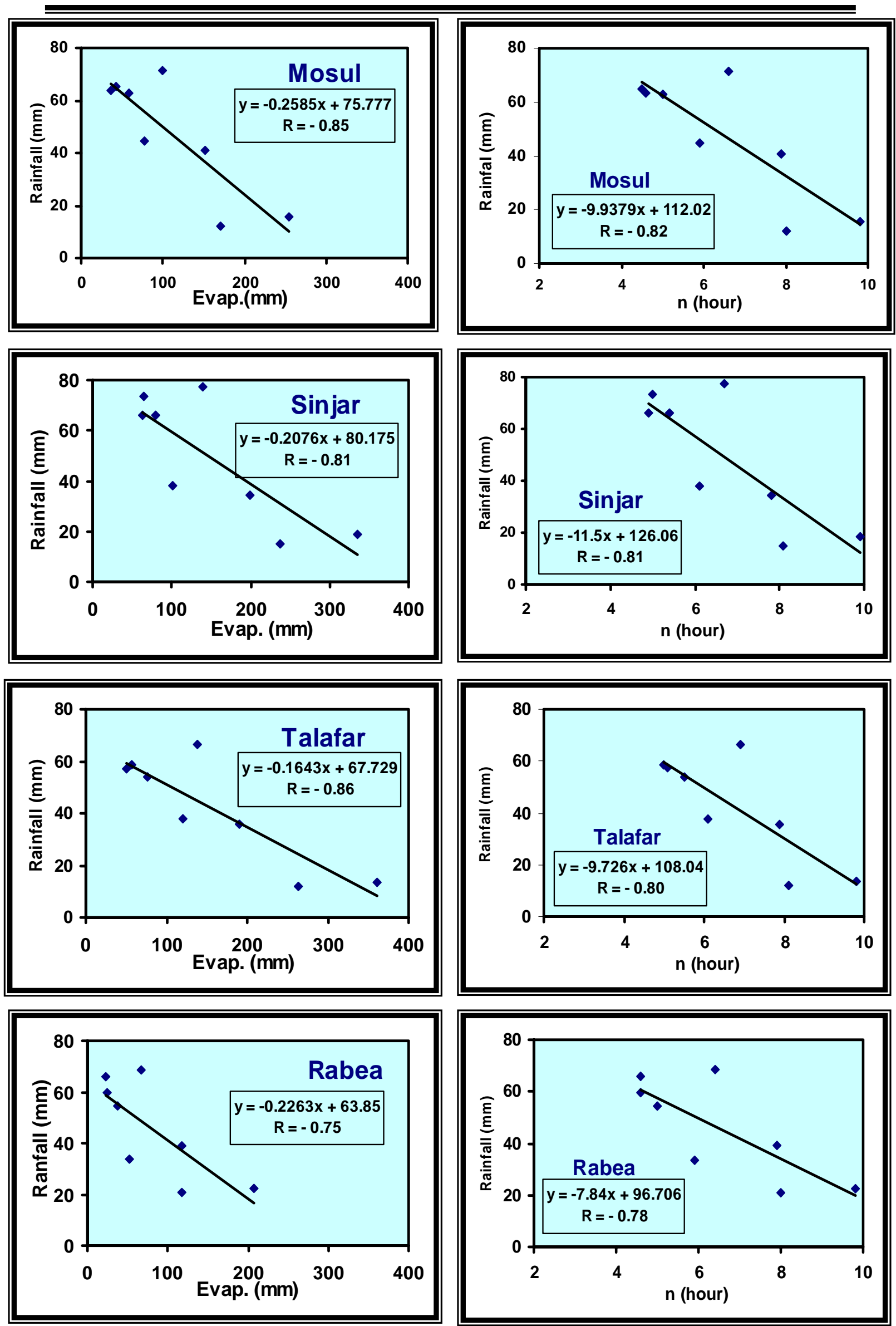

Fig. (13) : Correlations between the mean Monthly Values of Rainfall (mm) and Evap. for all Stations

Fig. (14) : Correlations between the mean Monthly Values of Rainfall (mm) and Sunshine hours for all Stations 
Spatial and Temporal Variation of Rainfall in Ninava Governorate.
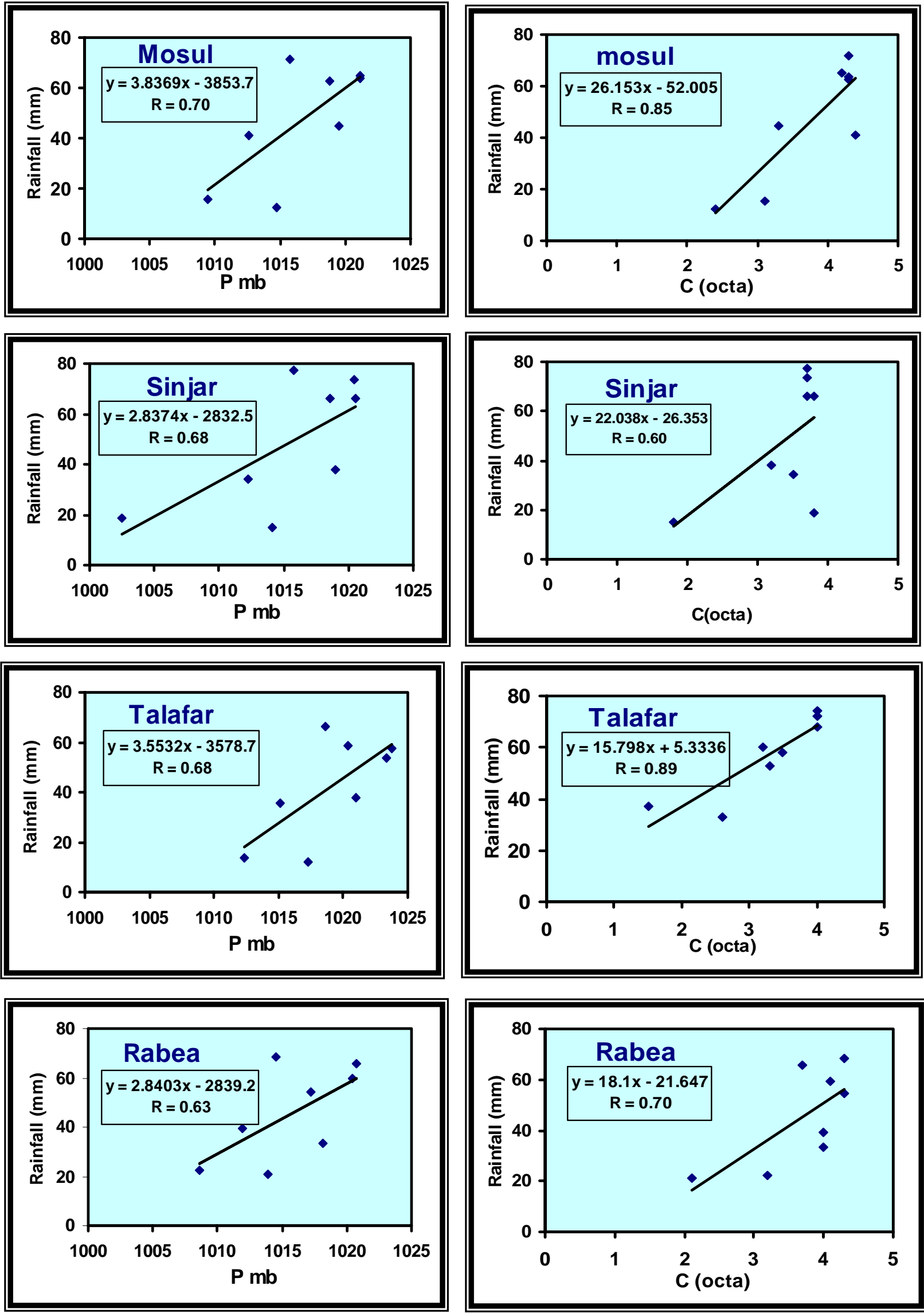

Fig. (15) : Correlations between the mean monthly values of rainfall $(\mathrm{mm})$ and pressure $(\mathrm{mb})$ in all stations.

Fig. (16): Correlations between the mean monthly values of rainfall $(\mathrm{mm})$ and

Cloudiness (octa) in all stations. 


\section{4- Study the frequency distribution of rainfall data}

Fig(17) Shows the frequency distribution of rainfall data for all stations on the rainy months.

The maximum frequency in October were found in the range (0-30) $\mathrm{mm}$ for all stations where its value are ranged between $(76-94) \%$.

In November the range $(0-30) \mathrm{mm}$ represent maximum frequency $(45-$ $52) \%$, the range $(30-60) \mathrm{mm}$ represent $(28-31) \%$ for all stations. The frequency between $(3-10) \%$ are represented the range $(90-120) \mathrm{mm}$. In December both the range $(0-30) \mathrm{mm}$ and the range $(30-60) \mathrm{mm}$ have values of frequency between $(17-59) \%$. The ranges $(60-90) \mathrm{mm},(90-$ $120) \mathrm{mm}$ and $(120-150) \mathrm{mm}$ have values between $(7-24) \%$.

All the ranges were appears in January but the maximum frequency were in the range $(30-60) \mathrm{mm},(31-49) \%$ for all stations.

In February the maximum value were in the ranges $(30-60)$ and $(60-$ 90) $\mathrm{mm}$, its value between $(14,66) \%$ for all stations.

In March the maximum frequency (31)\% in Mosul station were in the range $(0-30) \mathrm{mm}$, Sinjar station have the maximum frequency $(24) \%$ in the range $(0-30) \mathrm{mm}$ and $(30-60) \mathrm{mm}$. Talafar station have the maximum frequency $(31) \%$ in the range $(60-90)$, and Rabea station have the maximum frequency $(59) \%$ in the range $(30-60) \mathrm{mm}$.

In April the maximum frequency were in the range $(0-30) \mathrm{mm}$ and its value were between $(48-62) \%$ for all stations. In may the maximum frequency were in the range $(\mathrm{o}-30) \mathrm{mm}$ was value between $(73-87) \%$.

\section{Conclusion}

1) Sinjar station gave the higher value of $(S D)(58.8)$ in January and Mosul station gave the higher value of CV\% which reach $182 \%$ in May. It is indicate that rainfall values in Sinjar station are spread out over a large of values.

2) All the stations indicate slightly downward trend of the mean monthly rainfall time series.

3) December, January, February and March gave the highest values of rainfall comparing with the other rainy months in all stations, where it ranged between $(53.8-77.2) \mathrm{mm}$.

4) Sinjar station shows the highest value of mean annual value of rainfall $(389.1 \mathrm{~mm})$.

5) A highly negative correlation shown between mean monthly values of rainfall with each of (Temperature, Evaporation, and sunshine hours for all stations, while it gave a highly positive correlations with each of (Relative Humidity, presser, and cloudiness).

6) The Multiple regression coefficients were $(1,0.956,0.955,0.998)$ for the stations (Mosul, Sinjar, Talafer and Rabea) respectively.

7) The maximum frequency were found in October in the range $(0-30) \mathrm{mm}$ for all stations between $(76-94) \%$. 


\section{References}

1) K. Subramaya, (1984), "Engineering Hydrology", Tata McGraw Hill Publishing Company Limited.

2) Danielson, E.W, Levin J. and Abrams E., (2003), "Meteorology" second edition, McGraw - Hill publishing companies Inc.

3) EL - Kadi, A.K.A., (2001), " Variation of rainfall and condition in Gaza - Palestine: on a regional and global context" Islamic University of Gaza. Vol. 9, NO 2, P(41 - 66).

4) Bruce J.P. and Clark, R.H., (1980), "Introduction to Hydro metrology Pergaman press LTD.

5) Bonifacis, (2000), "A study of Rainfall variations in the Philippines $(1950$ - 1996)", Science Diliman (January - June 2000), 12-1, 1-28.

6) D. A. Bleej, (2003), "Evaluation of Precipitation in Duhok Governorate", Thesis, College of Science of Education, University of Dohok. (In English)

7) A.H. Daood, (2004), "Study of some Techniques for Processing Rainfall Time Series in the North part of Iraq", Thesis, College of Engineering, University of Mosul. (

8) S. Grimald, (2005), "Multivariate linear parametric models applied to daily rainfall time series", Italy, Advances in Geosciences, 2,8792, 2005.

9) Wauter Buytaent, (2006), "Spatial and Temporal rainfall variability in mountainous areas: A case study from the south Ecuadorian Andes", Journal of Hydrology.

10) K. Oduro -Afriyie, (2006), "Spectral characteristics at the Annual mean rainfall series in Chana", West Africa Journal at Applied Ecology, o355 - 4307, Volume 9. (Jan. - Jun. 2006).

11) Momani, (2009), "Time series Analysis Model for rainfall data in Jordan: Case study for using time series analysis", American Journal of Environmental Science, 5(5):599 - 604.

12) Abaje, (2010), "An analysis of rainfall trends in Kafanchan Earth Sciences, 2(2),89- 96 . 


\section{Lamia M. F. Mustafa}
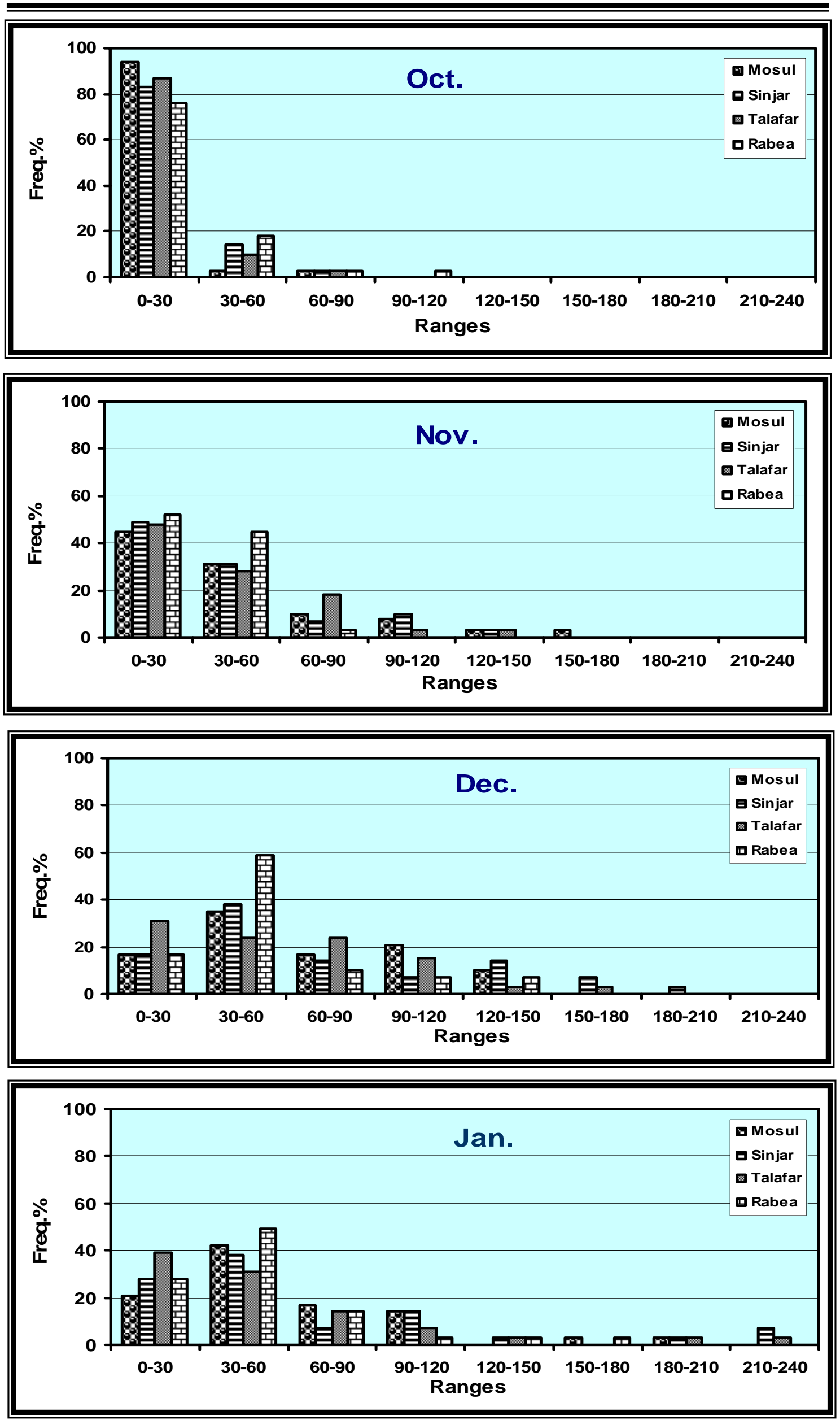
Spatial and Temporal Variation of Rainfall in Ninava Governorate.
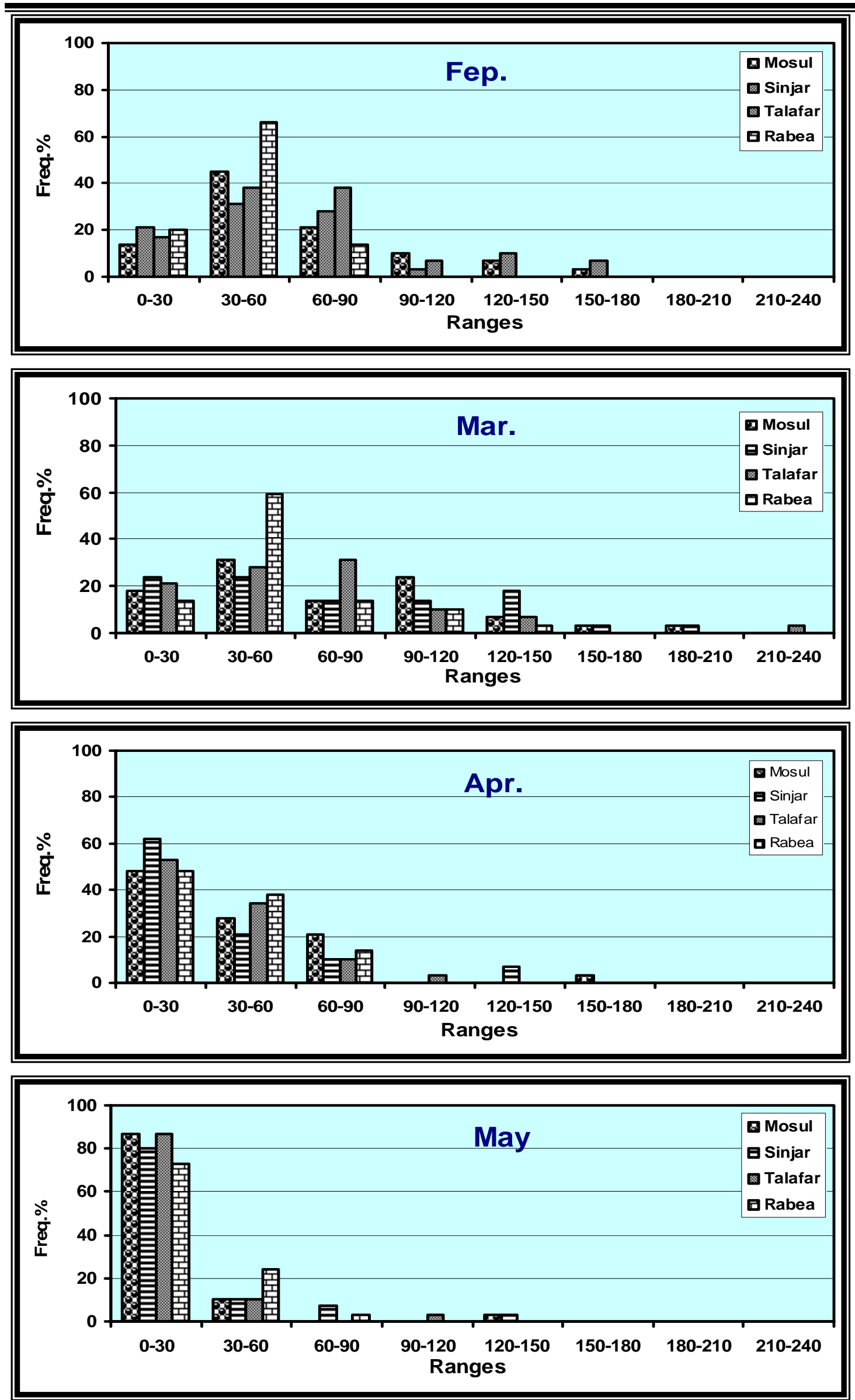

Fig (18) : Frequancy distribution of rainfall for all stations in rainny months. 
Appendix (1): The mean monthly of rainfall, SD, CV in Mosul, Sinjar, Talafar and Rabea

Mosul station

\begin{tabular}{|c|c|c|c|c|c|c|c|c|}
\hline Months & Oct. & Nov. & Dec. & Jan. & Feb. & Mar. & Apr. & May \\
\hline MEAN & 12.3 & 44.6 & 65.1 & 63.6 & 62.7 & 71.6 & 40.9 & 15.6 \\
\hline SD & 17.1 & 41.7 & 36.2 & 42.3 & 36.7 & 47.6 & 34.9 & 28.4 \\
\hline cv & 139 & 93.5 & 55.6 & 66.5 & 58.5 & 66.5 & 85.3 & 182 \\
\hline
\end{tabular}

Sinjar station

\begin{tabular}{|c|c|c|c|c|c|c|c|c|}
\hline Months & Oct. & Nov. & Dec. & Jan. & Feb. & Mar. & Apr. & May \\
\hline MEAN & 15.1 & 38.0 & 73.4 & 66.0 & 66.0 & 77.2 & 34.2 & 18.7 \\
\hline SD & 17.4 & 37.8 & 50.9 & 58.8 & 44.5 & 49.0 & 29.0 & 29.3 \\
\hline CV & 115.2 & 99.4 & 69.3 & 89.0 & 67.4 & 63.4 & 84.7 & 156.6 \\
\hline
\end{tabular}

Talafar station

\begin{tabular}{|c|c|c|c|c|c|c|c|c|}
\hline Months & Oct. & Nov. & Dec. & Jan. & Feb. & Mar. & Apr. & May \\
\hline MEAN & 12.1 & 37.8 & 58.5 & 57.4 & 53.8 & 66.3 & 35.6 & 13.7 \\
\hline SD & 18.7 & 37.2 & 38.8 & 54.8 & 28.5 & 45.1 & 25.4 & 19.3 \\
\hline CV & 154.5 & 98.4 & 66.3 & 95.4 & 53.0 & 68.0 & 71.3 & 140.8 \\
\hline
\end{tabular}

\section{Rabea station}

\begin{tabular}{|c|c|c|c|c|c|c|c|c|}
\hline Months & Oct. & Nov. & Dec. & Jan. & Feb. & Mar. & Apr. & May \\
\hline mean & 21 & 33.6 & 65.8 & 59.5 & 54.4 & 68.5 & 39.2 & 22.4 \\
\hline sd & 26.1 & 28 & 41.8 & 45.5 & 28 & 37 & 29.3 & 21.8 \\
\hline cv\% & 124 & 83.3 & 63.5 & 76.4 & 51.4 & 54 & 74.7 & 97.3 \\
\hline
\end{tabular}

